\title{
Communication
}

[Comunicação]

\section{Detection of papillomavirus DNA in formalin-fixed paraffin-embedded equine aural plaque samples}

\author{
[Detecção do DNA de papilomavírus em amostras de placa aural equina fixadas
} em formalina e embebidas em parafina]

\section{L.S. Zakia, R.M. Basso, G. Olivo, M. Herman, J.P. Araujo Jr., A.S. Borges, J.P. Oliveira-Filho"}

Faculdade de Medicina Veterinária e Zootecnia de Botucatu, Unesp Univ. Estadual Paulista, Botucatu, SP

Equine aural plaques were recently associated with four equine papillomaviruses (EcPVs) (Lange et al., 2013; Taniwaki et al., 2013). These viruses have been detected in fresh samples by PCR (Lange et al. 2013; Taniwaki et al., 2013), but EcPVs have not been identified in formalinfixed and paraffin-embedded (FFPE) aural plaque samples. Archives of FFPE aural plaques and other papilloma specimens stored in diverse veterinary diagnostic centers may represent a valuable source of material for the etiologic diagnosis of papillomaviruses involved in the disease (Newkirk et al., 2014); therefore, the aim of this study was to optimize a reliable method for the detection of the EcPVs in FFPE aural plaque samples by PCR.

Twenty-one rounded $(\leq 10-\mathrm{mm})$ aural plaques from horses of any age, sex, and breed from six farms in Sao Paulo State, Brazil, were obtained using a $6 \mathrm{~mm}$ disposable biopsy punch. The Institutional Ethical Committee (120/2013CEUA) approved all protocols. After the biopsy procedure the samples were fixed for $24 \mathrm{~h}$ in $10 \%$ neutral buffered formalin and then embedded in pure paraffin. Clinical and histopathological examinations were used to confirm the diagnosis of aural plaque (Gorino et al., 2013). Twenty slices (10- $\mu \mathrm{m}$ thick) were removed from each block and immediately placed into sterile microtubes. The microtome blade was changed and the equipment was cleaned to avoid DNA cross-contamination. Briefly, DNA was extracted (QIAamp DNA
FFPE tissue kit, Qiagen) following the manufacturer's instructions, without performing the xylene step. DNA purity was evaluated at the A260:A280 and A260:A230 ratios using the Nanodrop (Thermo Scientific) and the DNA was quantified using the Qubit (Life Technologies).

Four primer sets were designed (Primer Express, Life Technologies) to amplify specific fragments of the major capsid L1 protein of each of the four EcPVs previously associated with equine aural plaque (Table 1). The specificity of PCR primers was evaluated in silico with Basic Local Alignment Search Tool (National Center for Biotecnology Information/USA). PCR reaction contained $2.0 \mu \mathrm{L}$ of DNA, $10.0 \mu \mathrm{L}$ of GoTaq PCR Master Mix (Promega), 300nM each of primer, and $6.8 \mu \mathrm{L}$ of nuclease-free water. PCR assay was also performed to identify the equine $\beta$-actin reference gene (Oliveira-Filho et al., 2010).

All PCR products obtained were the predicted size of the each PCR set and were sequenced using the BigDye kit (Life Technologies) and the 3500 Genetic Analyzers (Life Technologies). The sequences were compared using the Basic Local Alignment Search Tool (National Center for Biotecnology Information/USA) with L1 sequences deposited in GenBank ${ }^{\mathrm{TM}}$ of each one of the four EcPVs. In addition, a 'no-template' control reaction was performed to verify the absence of contamination for each PCR.

Recebido em 22 de outubro de 2014

Aceito em 8 de junho de 2015

*Autor para correspondência (corresponding author)

E-mail: zefilho@fmvz.unesp.br 
Table 1. Nucleotide sequences of the primer sets designed to amplify specific fragments of the major capsid L1 protein of each of the 4 equine papillomaviruses DNA and of the primer set to amplify a fragment of the equine $\beta$-actin DNA (reference gene) by polymerase chain reaction

\begin{tabular}{|c|c|c|c|c|}
\hline Primer name & Primer sequence $\left(5^{\prime}-3^{\prime}\right)$ & $\begin{array}{l}\text { Amplified } \\
\text { fragment }\end{array}$ & $\begin{array}{l}\text { Annealing } \\
\text { temperature }\end{array}$ & GenBank $^{\mathrm{TM}}$ ID \\
\hline JPEcPV3 For & TTGCGCCAGGTTTCCACATCTA & \multirow{2}{*}{$116 \mathrm{bp}$} & \multirow{2}{*}{$60^{\circ} \mathrm{C}$} & \multirow{2}{*}{ GU384895 } \\
\hline JPEcPV3 Rev & TTGTTCTGGCCTTGTGCACGTT & & & \\
\hline JPEcPV4 For & ACAATGGTGTTTGCTGGCACGA & \multirow{2}{*}{$187 \mathrm{bp}$} & \multirow{2}{*}{$60^{\circ} \mathrm{C}$} & \multirow{2}{*}{ JF939718.1 } \\
\hline JPEcPV4 Rev & ACCGTGCAAAGCTGCAGAATGA & & & \\
\hline JPEcPV5 For & GGCTCCGTAGACATTCCTAAAG & \multirow{2}{*}{$184 \mathrm{bp}$} & \multirow{2}{*}{$62^{\circ} \mathrm{C}$} & \multirow{2}{*}{ YP007349388 } \\
\hline JPEcPV5 Rev & CTGTTACACCCACGCCTAAT & & & \\
\hline JPEcPV6 For & CTACCAGAGGAACGAGCTTTAC & \multirow{2}{*}{$203 \mathrm{bp}$} & \multirow{2}{*}{$62{ }^{\circ} \mathrm{C}$} & \multirow{2}{*}{ YP007518497 } \\
\hline JPEcPV6 Rev & TAGCTCCCAATCCTCCAAGATA & & & \\
\hline B-actin For $\$$ & CATTGTCCACCTTCCAGCAGATGT & \multirow{2}{*}{$86 \mathrm{bp}$} & \multirow{2}{*}{$62{ }^{\circ} \mathrm{C}$} & \multirow{2}{*}{ AF035774 } \\
\hline B-actin Rev $\ddagger$ & CTAGAAGCATTTGCGGTGGACGAT & & & \\
\hline
\end{tabular}

* Base pairs

$\uparrow$ Previously described ${ }^{6}$

The ratios of absorbance of the DNA samples varied between 1.8 and 2.1 , and the mean DNA concentration was $21.2 \mathrm{ng} / \mu \mathrm{L}$. $\beta$-actin DNA was amplified in all samples. EcPVs DNA was detected in 11 samples (52.4\%). EcPV4 DNA was detected in $38.1 \%(8 / 21)$ and EcPV3 in $4.8 \%$ $(1 / 21)$ of the samples. Co-infections were observed in two samples (9.5\%): EcPV4 and EcPV5 were detected simultaneously in one sample, as were EcPV4 and EcPV6 in another sample. Viral DNA was not detected in $47.6 \%$ $(10 / 45)$ of the samples. No-template control reactions were negative. The sequencing analysis confirmed the specificity of the amplificationpositive products $(100 \%$ homology).

DNA quality and yield are generally better from fresh specimens than preserved specimens, but the unavailability of fresh specimens may be a common roadblock to these studies, as tissue is typically submitted for histopathological examination (Woods et al., 2013). Therefore, FFPE samples represent an important source for retrospective studies (Newkirk et al. 2014); however, the use of an adequate fixation process to conserve tissue morphology may negatively affect nucleic acid preservation and may consequently also affect molecular diagnostic procedures (Barcelos et al., 2008). In the present study, the following measures were taken to minimize the adverse effects of the FFPE process: the samples used were approximately 6mm thick, a 10:1 ratio of formalin to tissue was used, neutral-buffered formalin solution was used instead of unbuffered formalin solutions, and a 24-h fixation time and pure paraffin were used. These strategies are generally used to avoid overfixation and to facilitate the extraction of usable nucleic acids (Barcelos et al., 2008; Qiagen, 2010). In the present study, the DNA quality and concentration were considered adequate for PCR procedures (Qiagen, 2010).

Although the technique of DNA extraction from FFPE tissues is considered robust and DNA can typically be extracted and amplified, preparations from fixed tissues always exhibit certain limitations for PCR (Qiagen, 2010). Therefore, a screening PCR assay using FFPE samples should be performed in parallel with reactions that amplify a housekeeping gene of similar size to ensure the DNA is not compromised and is amenable to PCR (Woods et al., 2013). In this study, a PCR assay for equine $\beta$-actin (reference gene) was used to confirm that the DNA purification methods were efficient and that the samples contained sufficient amplifiable DNA.

Recently, EcPV3 and EcPV4 (Gorino et al., 2013) and EcPV3, EcPV5, and EcPV6 (Lange et al., 2013) DNA were detected in fresh and cytobrush-collected aural plaque samples, 
respectively, by PCR. The current study is the first to report the DNA detection of these EcPVs in FFPE aural plaque samples. EcPV4 was the virus with the highest prevalence, which agreed with a previous study that reported EcPV4 DNAs in $37.8 \%(17 / 45)$ of fresh aural plaque samples by PCR (Gorino et al., 2013). Although these studies used different samples, conservation methodologies (fresh vs. FFPE), specific-primer and PCR methodologies, the common results may be explained by the inclusion of horses from the same region in both studies, suggesting a geographic component that has also been observed with the prevalence of human papillomavirus in ocular surface diseases (Woods et al., 2013). However, in a retrospective study no association was observed between the geographic origin of the sample and papillomavirus-positive test results in FFPE equine penile carcinoma samples (Newkirk et al., 2014).

In summary, the PCR methodology was adequate and may be used to diagnose these viruses in FFPE aural plaque samples. However, because $47.6 \%$ of the samples were PCR-negative, other EcPVs may be associated with equine aural plaques.

Keywords: horses, formalin-fixed and paraffinembedded samples, papillomaviruses, PCR

\section{RESUMO}

A placa aural é uma dermatopatia associada à quatro Equus caballus papillomavirus (EcPVs). Até o momento, o DNA de EcPVs não foi identificado em amostras de placa aural fixadas em formalina $e$ embebidas em parafina (FFPE). O objetivo deste estudo foi otimizar um método para a detecção dos quatro tipos de EcPVs em 21 amostras FFPE usando a PCR. O DNA dos EcPVs foram detectados em 11 amostras (52.4\%). O DNA do EcPV4 foi detectado em $38.1 \%$ (8/21) e do EcPV3 em $4.8 \%$ (1/21) das amostras. Coinfecção foi identificada em duas amostras (9.5\%); EcPV4 e 5 foram detectados simultaneamente em uma amostra, enquanto o DNA dos EcPV4 e 6 foi detectado em outra. A especificidade do DNA dos papilomavírus equinos foi avaliada por sequenciamento gênico direto, que confirmou a especificidade dos produtos. A metodologia de PCR proposta possibilita o diagnóstico dos EcPV3, 4, 5 e 6 em amostras FFPE de placa aural equina.

Palavras-chave: equino, papilomavírus, PCR, amostras fixadas em formalina e embebidas em parafina

\section{ACKNOWLEDGEMENTS}

The support of the São Paulo Research Foundation (FAPESP), processes 2012/06378-2, 2013/13973-7 and 2013/15995-8; and Research Pro-Reitoria of the Univ. Estadual Paulista (Unesp), process 1946/009/13-PROPe/CDC; are acknowledged.

\section{REFERENCES}

BARCELOS, D., FRANCO, M.F., LEÃO, S.C. Effects of tissue handling and processing steps on PCR for detection of Mycobacterium tuberculosis in formalin-fixed paraffin-embedded samples. Rev. Inst. Med. Trop. São Paulo, v.50, p.321-326, 2008.
CRITICAL factors for molecular analysis of FFPE samples. 2010. Available in: <https://www.qiagen.com/br/resources/resourced etail?id=00d71edd-0bc1-4901-8642-

4b55bd0ed47a\&lang=en>. Accessed: 15 september 2013.

GORINO, A.C., OLIVEIRA-FILHO, J.P., TANIWAKI, S.A. et al. Use of PCR to estimate the prevalence of Equus caballus papillomavirus in aural plaques in horses. Vet. J., v.197, p.903904, 2013.

LANGE, C.E., VETSCH, E., ACKERMANN, M. et al. Four novel papillomavirus sequences support a broad diversity among equine papillomaviruses. J. Gen. Virol., v.94, p.13651372, 2013. 
NEWKIRK, K.M., HENDRIX, D.V.H., ANIS, E.A. et al. Detection of papillomavirus in equine periocular and penile squamous cell carcinoma. J. Vet. Diagn. Invest., v.26, p.131-135, 2014.

OLIVEIRA-FILHO, J.P., BADIAL, P.R., CUNHA, P.H.J. et al. Cloning, sequencing and expression analysis of the equine hepcidin gene by real- time PCR. Vet. Immunol. Immunopathol., v.135, p.34-42, 2010.
TANIWAKI, A.S., MAGRO, A.J., GORINO, A.C. et al. Phylogenetic and structural studies of a novel equine papillomavirus identified from aural plaques. Vet. Microbiol., v.162, p.85-93, 2013.

WOODS, M., CHOW, S., HENG, B. et al. Detecting human papillomavirus in ocular surface diseases. Invest. Ophthalmol. Visual Sci., v.54, p.8069-8078, 2013. 